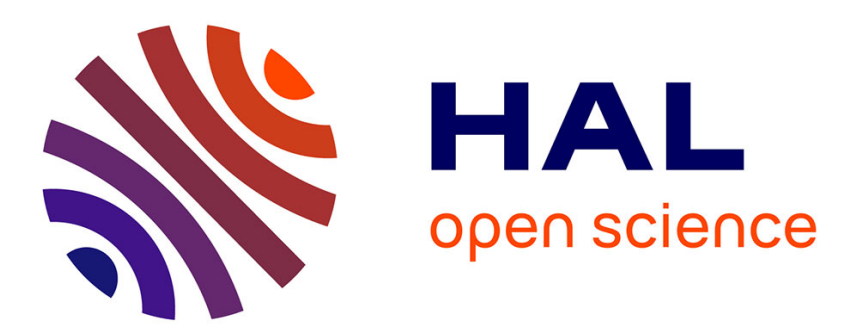

\title{
Microstructure of yttria stabilized zirconia-hafnia plasma sprayed thermal barrier coatings
}

H. Ibégazène, S. Alpérine, C. Diot

\section{To cite this version:}

H. Ibégazène, S. Alpérine, C. Diot. Microstructure of yttria stabilized zirconia-hafnia plasma sprayed thermal barrier coatings. Journal de Physique IV Proceedings, 1993, 03 (C7), pp.C7-1013-C7-1016. 10.1051/jp4:19937158 . jpa-00251781

\section{HAL Id: jpa-00251781 https://hal.science/jpa-00251781}

Submitted on 1 Jan 1993

HAL is a multi-disciplinary open access archive for the deposit and dissemination of scientific research documents, whether they are published or not. The documents may come from teaching and research institutions in France or abroad, or from public or private research centers.
L'archive ouverte pluridisciplinaire HAL, est destinée au dépôt et à la diffusion de documents scientifiques de niveau recherche, publiés ou non, émanant des établissements d'enseignement et de recherche français ou étrangers, des laboratoires publics ou privés. 


\title{
Microstructure of yttria stabilized zirconia-hafnia plasma sprayed thermal barrier coatings
}

\author{
H. IBÉGAZÈNE, S. ALPÉRINE and C. DIOT \\ ONERA, Materials Science Department, BP. 72, 92322 Châtillon cedex, France
}

\begin{abstract}
$\underline{\text { ABSTRACT }}$
Hafnia is an attractive candidate to build reliable and durable thermal barrier systems, due to its similarity to zirconia and its elevated structural transformation temperatures. We report here structural investigations of various plasma sprayed coatings composed of $\mathrm{ZrO}_{2}+\mathrm{x}$ mole $\% \mathrm{HfO}_{2}(\mathrm{x}=0,25,50$ and 100), partially stabilized by 4.53 mole \% yttria. X-Ray diffraction studies and TEM investigations show that, a metastable, non transformable, high yttrium content, $t$ ' phase is the only phase observed on the as-sprayed samples. Such results has not been yet related in the literature.
\end{abstract}

\section{INTRODUCTION}

The use of thermal barrier coatings to increase turbine engines' efficiency, which implies coatings high temperature components (vanes and blades) is still a technical challenge. For this purpose, the state of the art consists of a MCrAlY bond coat about $100 \mu \mathrm{m}$ thick covered by a $200-300 \mu \mathrm{m}$ thick $\mathrm{ZrO}_{2}-8$ wt $\% \mathrm{Y}_{2} \mathrm{O}_{3}$ top coat (this composition is equivalent to $4.5 \mathrm{~mol} \% \mathrm{Y}_{2} \mathrm{O}_{3}$ and $9 \mathrm{~mol} \% \mathrm{YO}_{1.5}$ ). Both can be plasma sprayed (low pressure plasma spray (LPPS) for the bond coat and air plasma sprayed (APS) for the ceramic). A major problem to solve in TBCs is that of coatings' thermomechanical resistance at elevated temperature (typically $1100^{\circ} \mathrm{C}$ and above). Many authors $[1,2]$ have shown that this property is closely related to the phase structure of the ceramic part of the coating. In the 6-8 wt $\% \mathrm{Y}_{2} \mathrm{O}_{3}$ composition range, a non-equilibrium tetragonal t' phase is retained at room temperature, because of rapid quenching during plasma spraying $[3,4]$. This t' phase displays particular faulted microstructural features, such as grain twinning and antiphase boundaries $[5,6]$. It has been pointed that these microstructural elements, absent outside this composition range, would act as crack deviation sites and thus enhance coating's intrinsic toughness.

In practice, however, the use of zirconia based TBC seems limited to temperature well below $1200^{\circ} \mathrm{C}$ for several reasons, one of which is the lack of perenniality of the ceramic microstructure. The aim of this study was to examine the phase microstructure in a new oxide system that would exhibit microstructures similar to that of zirconia and transform at higher temperatures. It has been tried in this paper to shed some light upon the influence of hafnia addition on the microstructure of plasma sprayed Y-PSZ coatings.

\section{EXPERIMENTAL}

The substrates used were $25 \times 50 \times 3 \mathrm{~mm}^{3}$ platelets of cast alloy $\mathrm{Ni}-23 \mathrm{Co}-20 \mathrm{Cr}-8.5 \mathrm{Al}-4 \mathrm{Ta}$, wt.\% (this composition matches that of the AMDRY 997, without yttrium), which were grit-blasted $\left(\mathrm{Al}_{2} \mathrm{O}_{3} 220\right.$ mesh, 2 bars) and degreased (vapor phase trichloroethylene). The substrates were first coated with a $100 \mu \mathrm{m}$ thick NiCoCrAlTaY bondcoat deposited by low pressure plasma spraying (from Ni-23Co-20Cr-8.5Al-4Ta-0.6Y wt.\%, AMDRY 997 powder). The samples were then heat treated during four hours at $1080^{\circ} \mathrm{C}$ under secondary vacuum $\left(\mathrm{P}_{\text {tot }}<10^{-5}\right.$ Torr $)$ 
for bondcoat diffusion and finally covered with a $300 \mu \mathrm{m}$ thick layer of $\left[(100-\mathrm{x}) \mathrm{ZrO}_{2}-\mathrm{x} \mathrm{HfO}_{2}\right]-4.5 \mathrm{~mol} \% \mathrm{Y}_{2} \mathrm{O}_{3}(\mathrm{x}$ $=0,25,50$ and $100 \mathrm{~mol} \%$ ). The ceramic was air plasma sprayed starting from ZIRCYT powders (mean diameter around $30 \mu \mathrm{m}$ ). The $4.5 \mathrm{~mol} \%$ of added yttria corresponds to a stabilization state equivalent to that of classical $\mathrm{ZrO}_{2}-8$ wt. $\% \mathrm{Y}_{2} \mathrm{O}_{3}$. X-ray diffraction data were obtained using a Philip PW 1380 Omega goniometer. The $\{111\}$ and $\{400\}$ regions of the $\mathrm{ZrO}_{2}$ diffraction patterns were extensively analyzed.

Electron-transparent thin foils for TEM have been prepared from coatings' planar sections by a technique fully described in [7]. They were studied using conventional transmission electron microscopy with Philips CM 20, JEOL $200 C X$ and JEOL $4000 \mathrm{FX}$ microscopes.

\section{RESULTS}

\section{X-ray analysis}

X-ray diffraction (XRD) analyses of as-sprayed samples show, for each composition ratio, the presence of a single tetragonal phase. Indeed, in these materials, the monoclinic polymorph is distinguished from the cubic and the tetragonal ( $t$ and $t^{\prime}$ ) polymorphs through the observation of the $\{111\}_{\mathrm{m}, \mathrm{t}}$ reflection (the pseudo-cubic description of the tetragonal phase is used here for convenience). On the other hand $c, t$ and $t$ ' can be differentiated by the separation of $\{400\}_{\mathfrak{c}},\{400\}_{\mathrm{t}},\{400\}_{\mathrm{t}^{\prime}},\{004\}_{\mathrm{t}}$ and $\{004\}_{\mathrm{t}^{\prime}}$, reflections at higher $2 \theta$ angles.

Partial X-ray diagrams in the $\{111\}$ region are shown for each sample in fig. 1 . The examination of this region shows the presence of the intense (111) reflection of the tetragonal phase and very weak $\{111\}$ reflections of the monoclinic phase (not visible on the figure). Some amount of monoclinic phase is also detected whatever the hafnia content. However, calculations based on peak heights above the background level [8] lead to consider this amount to be less than $2 \%$ for all samples. The equivalent $X$-ray diffraction patterns from the $\{400\}$ region are also shown in fig. 1. The presence of two peaks in this region is characteristic of $t$ or $t$ ' tetragonal phases.

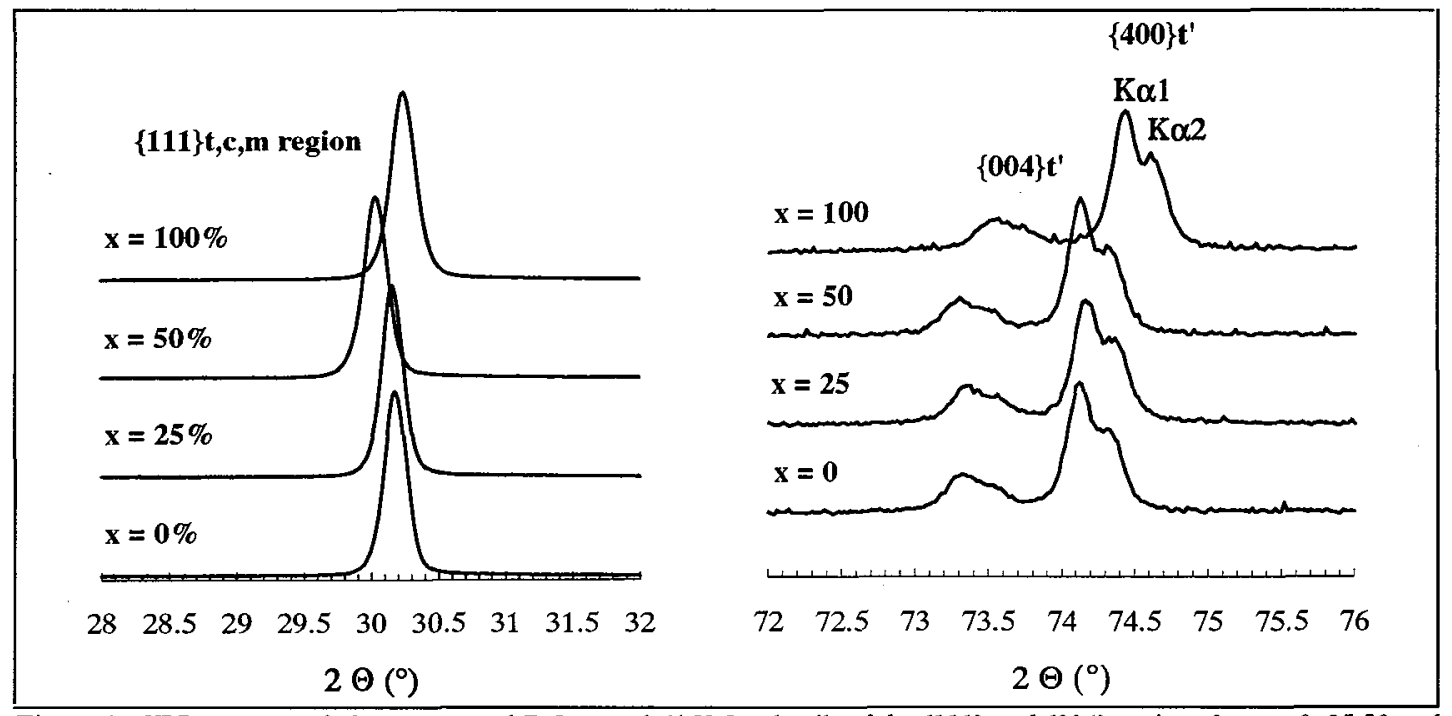

Figure 1:XRD patterns of plasma sprayed $\mathrm{ZrO}_{2}-x$ mol. $\% \mathrm{Y}_{2} \mathrm{O}_{3}$; details of the $\{111\}$ and $\{004\}$ regions for $x=0,25,50$ and 100.

Lattice parameters, measured by $\mathrm{XRD}$, provided indirect values of the percentage of yttria in the tetragonal phase according to the expressions derived from the experimental work by Scott [9]. For $x=0,25$ and 50 the high $\mathrm{Y}_{2} \mathrm{O}_{3}$ content of the tetragonal phase and c/a ratio close to unity suggest the presence of the metastable $t$ ' phase. For $\mathrm{x}=100$, agreement with high yttria content (ie $4.5 \mathrm{~mol} \% \mathrm{Y}_{2} \mathrm{O}_{3}$ ) is only obtained on the basis of c/a evaluation. This fact is not surprising considering the validity domain of Scott formulae and the slight difference between $\mathrm{Zr}^{4+}$ and $\mathrm{Hf}^{4+}$ ionic radii. 


\section{Ceramic microstructure}

The ceramic shows for all compositions a microstructure of fine equiaxed grains in the size range $0.1-1 \mu \mathrm{m}$. Some grains are slightly elongated sometimes. The fine characterization of the microstructure is achieved by using dark field imaging technique. Indeed, the tetragonality of the coating is revealed in experimental diffraction mode by the presence of weak reflections (forbidden for the F Bravais lattice) of the type \{odd, odd, even\} (with the relevant index permutations). Using these reflections, appearance of grain twinning and domains structure (tetragonal variants separated by APB) inside each diffracting twin is always displayed (see fig. 2). At a subgrain level the observed tetragonal phase also exhibits microstructural features similar to the well studied $t^{\text {' phase }}$ in $\mathrm{ZrO}_{2}-6$ to 8 wt. $\% \mathrm{Y}_{2} \mathrm{O}_{3}[6,10]$.

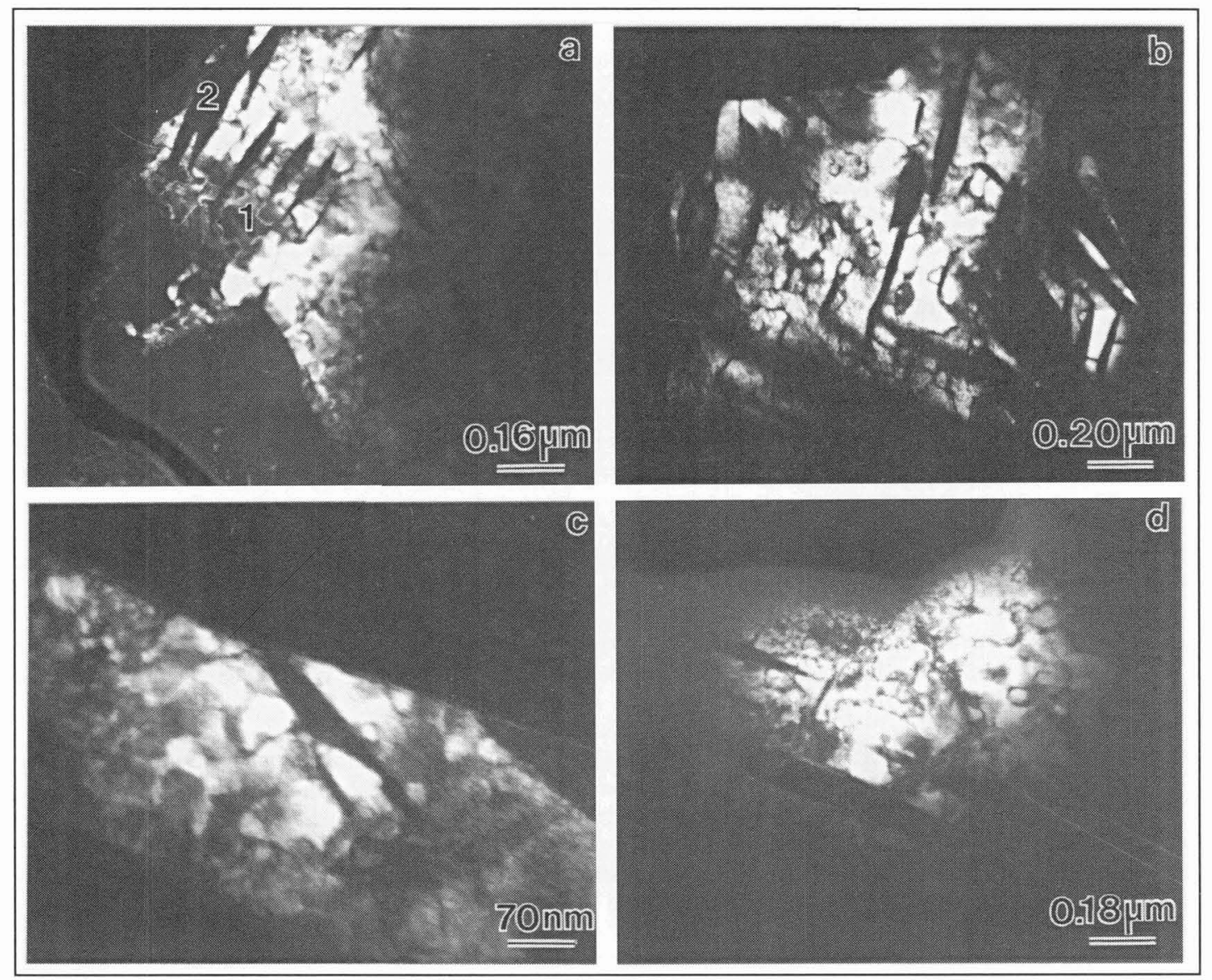

Figure 2: Dark field TEM image of tetragonal t' grains with $\langle 111>$ zone axis; $g=\{112\} ; 1) A P B, 2)$ extinguished twins; $x=0$ (a), $25(b), 50(c)$ and $100(d)$.

These microstructural features (domain microstructure and APBs inside the twins) result from the decrease of symmetry during the $c \rightarrow t^{\prime}$ displacive transformation [7]. Twin microstructure occurs because of the equivalent possibility for the tetragonal distortion to be along any of the three original $<100>$ axes of the parent cubic cells.

\section{DISCUSSION}

Generally speaking, the phase composition and microstructure of $\left(\mathrm{ZrO}_{2}-\mathrm{xmol} \mathrm{HfO}_{2}\right)-\mathrm{Y}_{2} \mathrm{O}_{3}$ coatings are in good agreement with our expectations. It has been shown unambiguously that all coatings are composed of a single 
tetragonal phase. This phase is the equivalent of the so-called t' phase [10] in the Y-PSZ systems, since:

(i) Its yttrium content matches that of the initial powder $\left(\sim 4.5 \mathrm{~mol} \% \mathrm{Y}_{2} \mathrm{O}_{3}\right)$.

(ii) The measured $\mathrm{c} / \mathrm{a}$ ratios only slightly depart from unity (less than $1 \%$, to be compared with the c/a of about 1.03 in the transformable equilibrium $t$ phase).

(iii) It does not transform into monoclinic, even when mechanical energy is being supplied (ground coatings).

To this regard, the similarities of the $\mathrm{Hf}^{4+}$ and $\mathrm{Zr}^{4+}$ cations lead to the formation of identical metastable phases during rapid quenching.

On a microstructural point of view, twinning of the t' grains and pseudo- antiphase boundary planes have been observed bearing great similarities with those previously reported by Lelait et al. [6, 7] in pure yttria partially stabilized zirconia coatings.

\section{SUMMARY}

The potentialities of hafnia as a ceramic material to be totally or partially substituted to zirconia to form plasma sprayed thermal barrier coatings have been investigated. It has been shown that the similarities between the $\mathrm{ZrO}_{2}-\mathrm{Y}_{2} \mathrm{O}_{3}$ and $\mathrm{HfO}_{2}-\mathrm{Y}_{2} \mathrm{O}_{3}$ equilibrium phase diagrams also extend to the formation of non-equilibrium phases. Yttria partially stabilized zirconia-hafnia mixtures all exhibit upon fast quenching a single metastable t' phase with a microstructure equivalent to that of pure YPSZ t' phase.

\section{REFERENCES}

[1] MILlER, R. A., SMIALEK, J. L., and GARLICK, R. G., 1981, "Phase Stability in Plasma-Sprayed Partially Stabilized Zirconia-Yttria," Heuer, A. H., and Hobbs, L. W., ed., Advances in Ceramics, Vol. 3, The American Ceramic Society, Columbus, OH, pp. 241-253.

[2] MILLER, R. A., GARLICK, R. G, and SMIALEK, J. L., 1983, "Phase Distribution in Plasma-Sprayed Zirconia-Yttria", Ceramic Bulletin, Vol. 62, N²12, pp. 1355-1358.

[3] ANDERSON, C. A., and GUPTA, T. K., 1981,"Phase Stability and Transformation Toughening in Zirconia," in Science and Technology of Zirconia, Advances in Ceramics, Vol. 3, The American Ceramic Society, Columbus, OH, pp. 184-201.

[4] LANTERI, V. CHAIM R., and HEUER, A. H., 1986, "On the Microstructures Resulting from the Diffusionless Cubic $\rightarrow$ Tetragonal Transformation in $\mathrm{ZrO}_{2}-\mathrm{Y}_{2} \mathrm{O}_{3}$ Alloys, Journal of The American Ceramic Society, Vol. 69, $\mathrm{N}^{\circ} 10$, pp. 258-261.

[5] ALPÉRINE, S., and LELAIT, L., 1992, "Microstructural Investigation of Plasma Sprayed Yttria Partially Stabilized Zirconia TBC," to be published in the Transaction of the ASME.

[6] LELAIT, L., and ALPÉRINE, S., 1991, "TEM Investigations of High Toughness Non-Equilibrium Phases in the $\mathrm{ZrO}_{2}-\mathrm{Y}_{2} \mathrm{O}_{3}$ System," Scripta Metallurgica et Materiala, Vol. 25, pp.1815-1820.

[7] LELAIT, L., 1991, "Etude Microstructurale fine de Revêtements Céramiques de type Barrière Thermique; Incidence sur la Résistance thermomécanique de ces Revêtements," Thèse, Université d’Orsay, France.

[8] IBÉGAZÈNE H., ALPÉRINE S., and DIOT C., 1993, "Yttria stabilized Hafnia-Zirconia Thermal Barrier Coatings," to be published in the Transaction of ASME.

[9] SCOTT, M. G., 1975, "Phase Relationship in the Zirconia-Yttria System," Journal of Materials Science, Vol. 10, pp. 1527-1535.

[10] LANTERI, V., "The Tetragonal Phase in Yttria Partially Stabilized Zirconia," Ph.D. Thesis, Case Western Reserve University, Cleveland, $\mathrm{OH}$. 